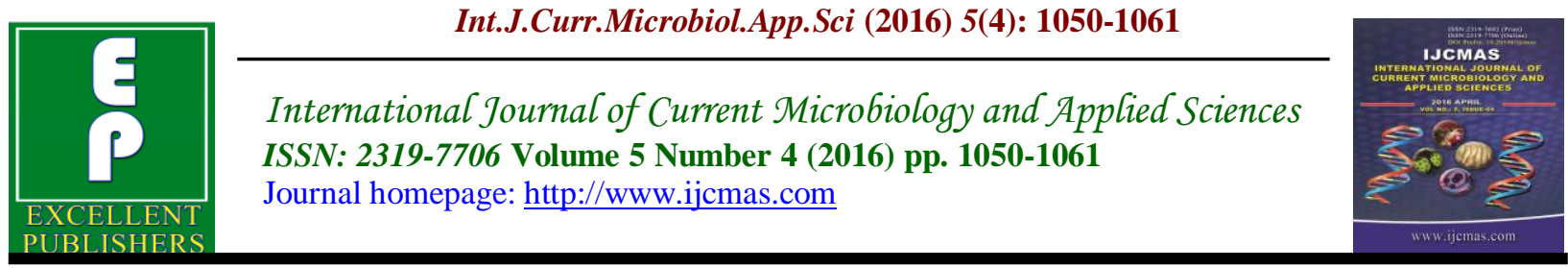

Original Research Article

http://dx.doi.org/10.20546/ijcmas.2016.504.120

\title{
Response of Free and Immobilized Uricase from Fenugreek Leaves to various treatments and Digestive Enzymes
}

\author{
Hamed M. El-Shora ${ }^{1 *}$, AbdelAziz F. AbdelAziz ${ }^{2}$ and Hoda M. Kondi ${ }^{1}$ \\ ${ }^{1}$ Botny Department, Faulty of Science, Mansoura University, Egypt \\ ${ }^{2}$ Chemistry Department, Faulty of Science, Mansoura University, Egypt \\ *Corresponding author
}

\begin{abstract}
A B S T R A C T
Keywords

Free and

Immobilized

Uricase,

Fenugreek

Leaves,

Digestive

Enzymes

Article Info

Accepted:

20 March 2016

Available Online:

10 April 2016

Uricase (Urate: oxygen oxidoreductase (EC 1.7.3.3) was isolated from 15-day old Trigonella foenum-graecum L. seedlings. Kinetin, gibberellin (GA3) and benzylaminopurine induced the enzyme and kinetin was the best inducer. The polyols including mannitol, sorbitol, glycerol,erythritol and xylitol expressed appreciable thermostability for uricase at $60^{\circ} \mathrm{C}$. Xylitol was better than trehalose as stabilizer at $60{ }^{\circ} \mathrm{C}$. The enzyme was then purified using $80 \%$ ammonium sulfate, DEAE-cellulose, and Sephadex G-200. The final specific activity was 80 units mg1 protein. The purified uricase was immobilized on alginate (entrapped) and alginate with glutaraldehyde activity (cross-linked). The cross-linked method was better than entrapped method. The Vmax values were 15.6, 13.8 and 15.2 units mg1 protein for the free, entrapped and cross-linked enzyme, respectively. The $\mathrm{Km}$ values were $0.072,0.092$ and $0.084 \mathrm{mM}$, respectively. The optimal $\mathrm{pH}$ was 8.5 for the free, entrapped, and cross-linked enzyme. The optimal temperature was $35^{\circ} \mathrm{C}$, for free and entrapped but it was $45^{\circ} \mathrm{C}$ for cross-linked uricase. Uricase exhibited appreciable resistant digestion by pepsin and trypsin.
\end{abstract}

\section{Introduction}

Uric acid (2, 6, 8-trihidroxypurine) is the final product of purine metabolism in human body. The high concentration of uric acid in the blood caused hypertension and cardiovascular diseases (Abbas, 2016). Therefore, uric acid detection method is very important to develop.

Microorganisms, animals and higher plants are capable of producing uricase on its own, but human being cannot produce uricase because of the mutation in the fifth exon of uricase gene (Nanda et al., 2012).
In higher plants, purine degradation has been studied particularly in legumes which grow symbiotically with nitrogen-fixing bacteria, where degradation leads to ureides (allantoin and allantoic acid) which play an important role in nitrogen mobilization in many nodulated plants (Atkins, 1991).

Uricase (EC 1.7.3.3, UC) is an enzyme belonging to the class of the oxidoreductases and catalyzes the oxidation of uric acid to allantoin, and thus plays an important role in the purine degradation 
pathway. Uricase in its conjugated form can be used as a therapeutic enzyme for the treatment of hyperuricemia and gout (Nancy et al.,. 2006).

Uricase in its conjugated form can be used as a therapeutic enzyme for the treatment of hyperuricemia and gout (Nancy et al., 2006). Furthermore, immobilized uricase can be used as a uric acid concentrations (Ademek et al., 1989).

Uricase was found in cotyledons (Theimer and Beevers, 1971) and soybean leaf (Christensen and Jochimsen, 1983).This work aimed to isolate, purify, immobilize uricase from Trigonella leaves compare the characteristics of free and immobilized uricase.

\section{Materials and Methods}

\section{Plant Material and Germination}

Pure strain of Trigonella foenum-graecum L was obtained from Egyptian Ministry of Agriculture. Seeds were germinated according to El-Shora (2002) and 15-day old seedlings were collected and leaves were used for the present investigation.

\section{Enzyme Extraction}

Leaves (10gm) of Trigonella foenumgraecum L. were suspended in $50 \mathrm{ml}$ of prechilled $20 \mathrm{mM}$ phosphate buffer $(\mathrm{pH}$ 7.0) and the mixture was blended in warren blender and stirred. The resulting homogenate was centrifuged at 10,000 rpm for $10 \mathrm{~min}$. The supernatant constitutes the crude enzyme extract which was used for subsequent analysis (El-Shora, and AboKassem, 2001).

\section{Assay of Uricase}

Uricase activity was assayed according to
Klose et al., (1978). The reaction mixture contained $2 \mathrm{ml}$ of $10 \mathrm{mM}$ uric acid in $100 \mathrm{mM}$ sodium borate buffer ( $\mathrm{pH} 8.5$ ), $0.2 \mathrm{ml}$ of 50 $\mathrm{mM}$ 4-aminoantipyrine, $0.2 \mathrm{ml}$ of $15 \mathrm{U} / \mathrm{ml}$ peroxidase from horseradish, $0.2 \mathrm{ml}$ of $2 \%$ phenol, $0.2 \mathrm{ml}$ of $100 \mathrm{mM}$ sodium borate buffer $(\mathrm{pH} 8.5)$ and $0.2 \mathrm{ml}$ of enzyme solution to a final volume of $3.0 \mathrm{ml}$. The mixture was incubated at $30^{\circ} \mathrm{C}$ for $10 \mathrm{~min}$ and the increase in absorbance was measured was spectrophotometrically at 505 $\mathrm{nm}$. One unit of uricase is defined as the amount of enzyme that produces 1.0 mole of $\mathrm{H} 2 \mathrm{O} 2$ per minute under standard assay conditions.

\section{Determination of Protein Concentration}

Protein concentration was determined according to Bradford (1967) with BSA as standard.

\section{Effect of Phytohormones}

The 7-day old seedlings were treated with $100 \mu \mathrm{mol}$ of kinetin, GA3 and benzylaminopurine for $72 \mathrm{~h}$ followed by enzyme assay.

\section{Effect of Polyols and Sugars}

The thermostability of purified free enzyme at $60{ }^{\circ} \mathrm{C}$ was investigated in presence of $10 \mathrm{mM}$ of mannitol, sorbitol, erythritol, sucrose, glucose, and $10 \%$ glycerol.

\section{Purification of Uricase}

The purification of uricase was done through three steps including ammonium sulfate precipitation, ion exchange and gel filtration chromatography. Ammonium sulfate was added to the crude uricase until it reached to $80 \%$ saturation. Precipitation of the protein was carried out by leaving the solution for $24 \mathrm{~h}$ at $4{ }^{\circ} \mathrm{C}$. A column of DEAE(diethylaminoethyl) cellulose was prepared 
and the desalted uricase was poured on the surface of column $(2 \times 50 \mathrm{~cm})$. The elution of sample was carried out with $100 \mathrm{mM}$ phosphate buffer ( $\mathrm{pH}$ 6.0). A column of Sephadex G-100 (3 x $50 \mathrm{~cm}$ ) was prepared and the eluent from the previous step was added. Elution was then carried out by $100 \mathrm{mM}$ phosphate buffer ( $\mathrm{pH} 8.0)$. A total of 20-fractions of three-ml each were collected. The enzyme activity was assayed and the protein estimation was carried out. Fractions containing enzyme activity were pooled and used for enzyme assay.

\section{Immobilization of Uricase}

The immobilization of uricase by entrapment was carried out according to ElShoraet al.,. (2015). The pure enzyme was added to $50 \mathrm{ml}$ sodium alginate $(3 \% \mathrm{w} / \mathrm{v})$. The solution was placed in a separating funnel and suspended over a beaker containing $150 \mathrm{ml} \mathrm{CaCl} 2$. The alginate bead was prepared by gentle dropping of the alginate solution through a $200 \mu \mathrm{l}$ Eppendorf tip into $\mathrm{CaCl} 2$ solution ( 30 drops $\min -1$ ). After $2 \mathrm{~h}$ of gentle stirring the bead was filtered out of the $\mathrm{CaCl} 2$ solution and thoroughly washed. The activity of the immobilized uricase was assayed.Crosslinking method for uricase immobilization was carried out by addition of $5 \% \quad(\mathrm{v} / \mathrm{v})$ glutaraldehyde.

\section{Effect of Uric Acid on Uricase Activity}

The activity of the two forms of immobilized uricase from Trigonella leaves were determined at various concentrations of uric acid $(0.2,0.4,0.6,0.8,1.0$ and 1.2.Lineweaver - Burk plot of uricase was carried out by plotting $1 / \mathrm{v}$ against $1 / \mathrm{s}$ and vmax and $\mathrm{Km}$ were calculated.

\section{Effect of Ph on Uricase Activity}

The activity of free, entrapped and cross- linked uricase was determined at $\mathrm{pH}$ values $6.5,7.0,7.5,8.0,8.5,9.0,9.5$ and 10 .

\section{Effect of Temperature on Uricase Activity}

The activity of free, entrapped and crosslinked uricase was determined at various incubation temperatures $25,30,35,40,45$, 50,55 and $60^{\circ} \mathrm{C}$.

\section{Effect of Digestive Enzymes on Uricase Activity}

The activity of free and immobilized uricase by cross-linking was measured after incubation with 200 units of trypsin or pepsin for various time intervals $(20,40,60$, 80 and $100 \mathrm{~min}$ ).

\section{Desorption of Entrapped and Cross- linked Enzyme}

Both entrapped and cross-linked uricase was treated with various concentrations $(0.3$, $0.6,0.9,1.2,1.5,1.8$ and $2 \mathrm{mM}$ ) of sodium dodecylsulphate (SDS) followed by measuring the desorptivity.

All the data in the present study are expressed as mean $\pm \mathrm{SE}$ obtained from three measurements.

\section{Results and Discussion}

The results in Fig. 1 reveal that uricase was inducedby kinetin, gibberellic acid (GA3) and benzylaminopurine. GA3 activated other enzymes including phosphoenolpyruvate carboxylase (Bihzad and El-Shora, 1996), sucrose phosphate synthase (Kaur et al., 2000), NADHglutamate synthase (El-Shora, 2001), acid phosphatase (El-Shora and Metwally, 2009) and glutaminase (El-Shoraand El-Naqeb, 2014). Kinetin induced carbonic anhydrase (Shah, 2008). 
It is possible that phytohormones can increase the enzyme activity through acting at the level of transcription (Hayat et al., 2001). It is also possible that phytohormones can increase the enzyme activity through acting at the level of the stabilization of the transcripts.

All polyhydric alcohols particularly mannitol (Fig. 2) had a positive effect against thermal denaturation. According to literature, the protective effect of polyols depends on the increasing number of hydroxyl groups (Graber and Cobes., 1989). However, in the present experiment, the effect of the length of the polyhydric alcohol molecule was not clearly observed.

The phenomenon of protein stabilization by polyhydric alcohols may be explained by changes in the microenvironment of the enzyme, which result in a more rigid conformation of the enzyme structure. Probably, the benefit of polyols is related to the effect they promote by increasing the degree of organization of water molecules, which in turn, intensify the hydrophobic interactions among nonpolar groups. Hydrophobic interactions appear to be the single most important factor to stabilize protein structure, therefore making the protein more resistant to unfolding (Triantafyllou et al., 1997).

Polyols are by far the best co-solvent for their ability of maintaining both solvophobic interactions and have the capability to form hydrogen bonds that support the native configuration of the protein stabilization (Bhosale et al., 2016). Trehaloseas disaccharide protected uricase (Fig.3) against heat inactivation but with higher stabilizing factor than mannitol. Theseare in harmony with those reported by ElShoraand Metwally (2009) for $\alpha$-glucosidase enzyme. Trehalose probably protects proteins by stabilizing their most compact structure, therefore reducing backbone movements away from the fully folded state (Nirmal and Laxman, 2014). The degree of structural protection conferred by sucrose correlates with the extent of hydrogen bonding potential and the polarization of the backbone permanent dipole which induce an increase in hydrogen bonding character of neighboring polar residues. In this regard Sola-Penna and Meyer-Fernandes, (1998) proposed that trehalose has a larger hydrated volume than other carbohydrates such as maltose, sucrose, and glucose facilitating preferential hydration and stabilizing proteins.

Enzyme purification techniques are required whenever commercial use of enzymes is made. The repeated estimation of enzymes is required at different steps of the purification process to find out the effectiveness of the process. Uricase in the present investigation was purified using 80 $\%$ ammonium sulfate, DEAE-cellulose and Sephadex G200 (Table 1) with specific activity of 80 units $\mathrm{mg}-1$ protein.

The immobilization of uricase on alginate (entrapped) or alginate plus glutaraldehyde (cross-linked)was carried out (Fig. 4). The cross-linking uricase exhibited $90 \%$ immobilization whereas the entrapment showed only $70 \%$ immobilization. Enzyme immobilization causes an increase in enzyme rigidity which is commonly reflected by an increase in stability towards denaturation by raising the temperature (Chang and Juang, 2005).

The results in Fig. 5 reveal that there was a gradual increase in uricase activity with increasing uric acid concentration for free, entrapped and cross-linked uricase. Plotting $1 / \mathrm{v}$ against $1 / \mathrm{s}$, where $\mathrm{v}$ is the velocity of the reaction and $s$ is the concentration of uric acid exhibited straight lines for the three forms of uricase (Fig. 6). The 
intercept of $1 / \mathrm{v}$ represents the value of Vmax and the intercept 1/s represent $\mathrm{Km}$ value. The $V \max$ values were 15.6, 13.8 and 15.2 units mg-1 protein for the free and cross-linked enzyme, respectively. The $\mathrm{Km}$ values were $0.072,0.092$ and $0.084 \mathrm{mM}$, respectively. Several reasons can account for the variations of the $\mathrm{km}$ values and vmax values of the enzyme upon immobilization. Among the reasons are the interactions of the enzyme molecules with the bead surface. This interactions might have induced an inactive conformation to the enzyme molecules. It should be noted that the immobilization process does not control the proper orientation of immobilized enzyme on the support (Yildiz, 2005). This improper fixation and /or the substrate the change in the property of the active sites might hinder the active site for binding of the substrate to the immobilized enzyme molecules.

The optimal $\mathrm{pH}$ of uricase from Trigonella leaves was 8.5 (Fig. 7) for the free, entrapped, and cross-linked enzyme as indicated from. Ohe and Watanabe (1981) reported highest uricase activity from Streptomyces cyanogenus at 8.0. Huang and $\mathrm{Wu}$ (2004) reported that the highest activity of uricase was at $\mathrm{pH}$ values $(\mathrm{pH}$ 6-11) from Candida subtilis. Abdullah and Flayyih (2015) recorded $\mathrm{pH}$ optimal of 9.0 for the enzyme from Pseudomonas aeruginosa.

The optimal temperature of uricase (Fig.8) was $35^{\circ} \mathrm{C}$, for free and entrapped but it was $45^{\circ} \mathrm{C}$ for cross-linked uricase. However, the optimal temperature of uricase was $45^{\circ} \mathrm{C}$ for the enzyme from Pseudomonas aeruginosa (Abdullah and Flayyih, 2015).

Table.1 Purification of Uricase from Trigonella foenum-graecum

\begin{tabular}{|l|c|c|c|c|c|}
\hline Purification step & $\begin{array}{c}\text { Total protein } \\
(\mathrm{mg})\end{array}$ & $\begin{array}{c}\text { Total } \\
\text { Activity }(\mathrm{U})\end{array}$ & $\begin{array}{c}\text { Specific activity } \\
\left(\mathrm{U} \mathrm{mg}^{-1} \text { protein) }\right.\end{array}$ & $\begin{array}{c}\text { Yield } \\
(\%)\end{array}$ & $\begin{array}{c}\text { Fold of } \\
\text { purification }\end{array}$ \\
\hline Crude extract & 168 & 24 & 0.14 & 100 & 1 \\
\hline $\begin{array}{l}\text { Ammonium } \\
\text { sulfate (60-80\%) }\end{array}$ & 121 & 22 & 0.18 & 92 & 1.29 \\
\hline DEAE-cellulose & 80 & 18 & 0.22 & 75 & 1.57 \\
\hline Sephadex G-200 & 0.20 & 16 & 80 & 67 & 571 \\
\hline
\end{tabular}

Fig.1 Effect of Phytohormones on Uricase Activity

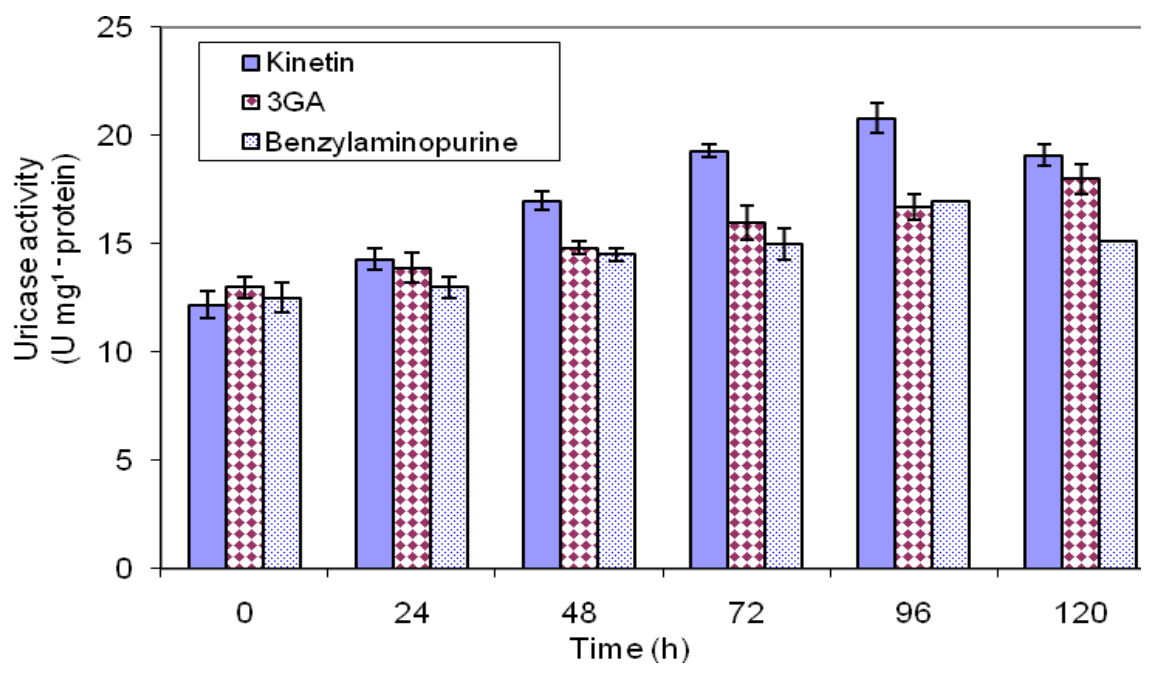


Fig.2 Effect of various Additives on Thermostability of Uricase at $60^{\circ} \mathrm{C}$

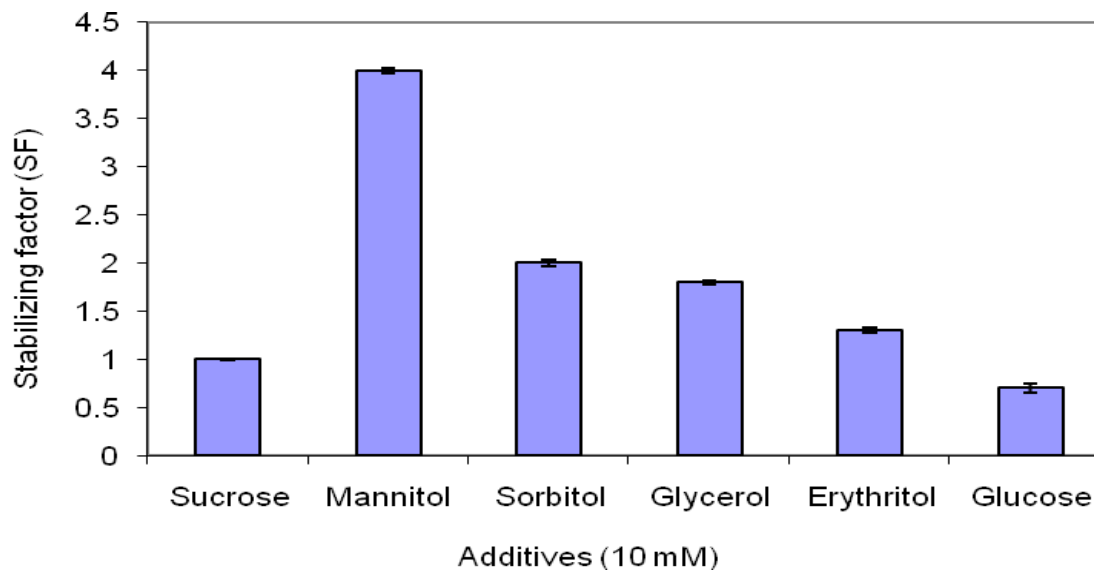

Fig.3 Effect of various Additives on Thermostability of Uricase at $60^{\circ} \mathrm{C}$

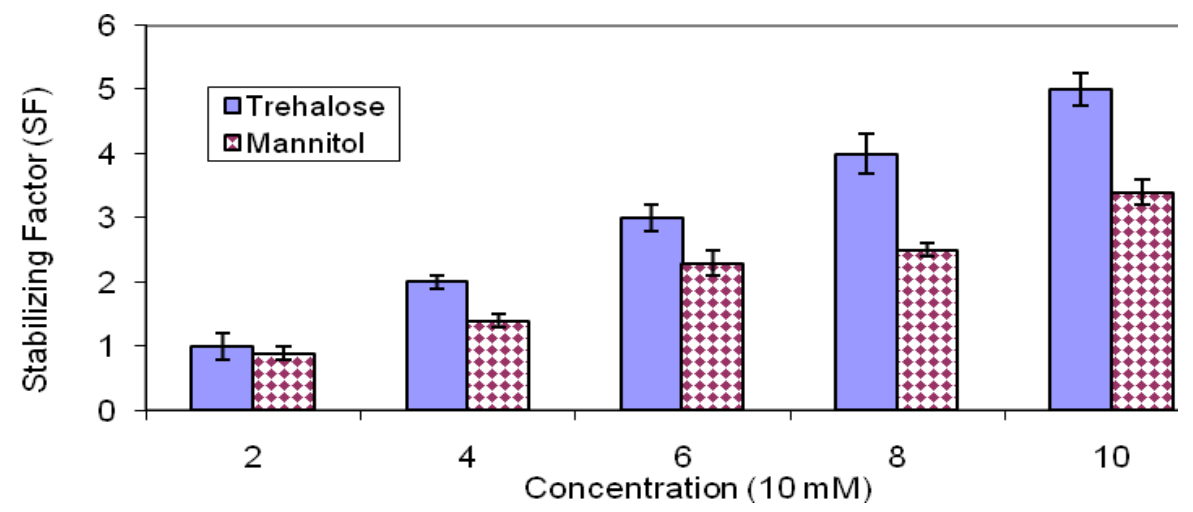

Fig.4 Immobilization of Uricase by Entrapment and Cross-linked Methods

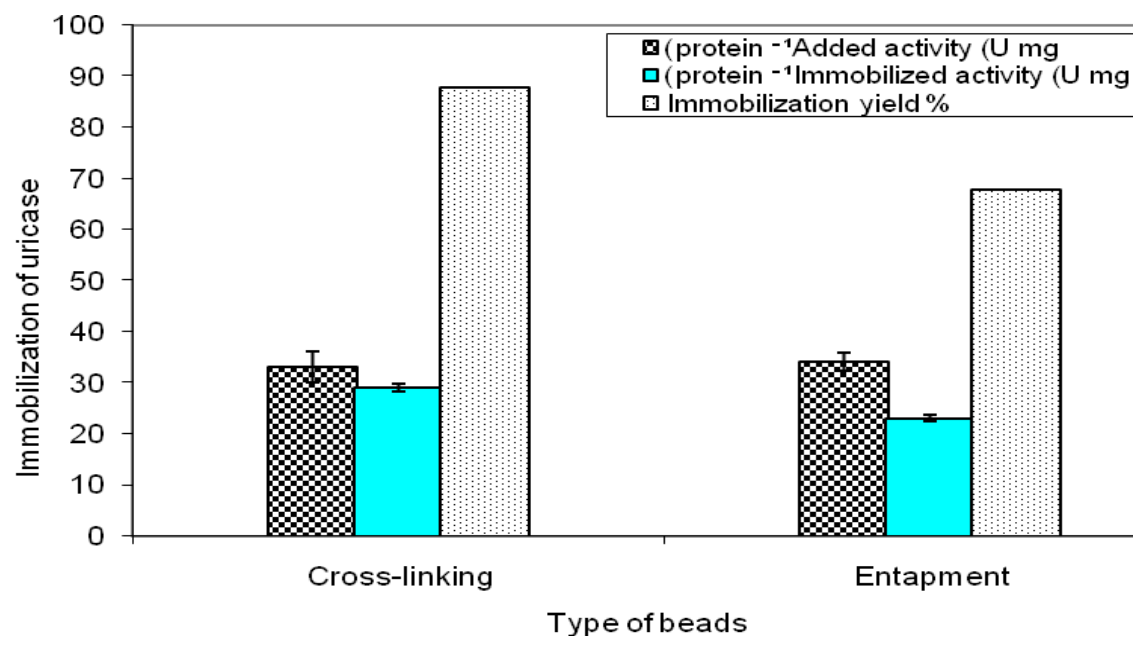


Fig.5 Effect of various Concentration of Uric acid on Uricase Activity

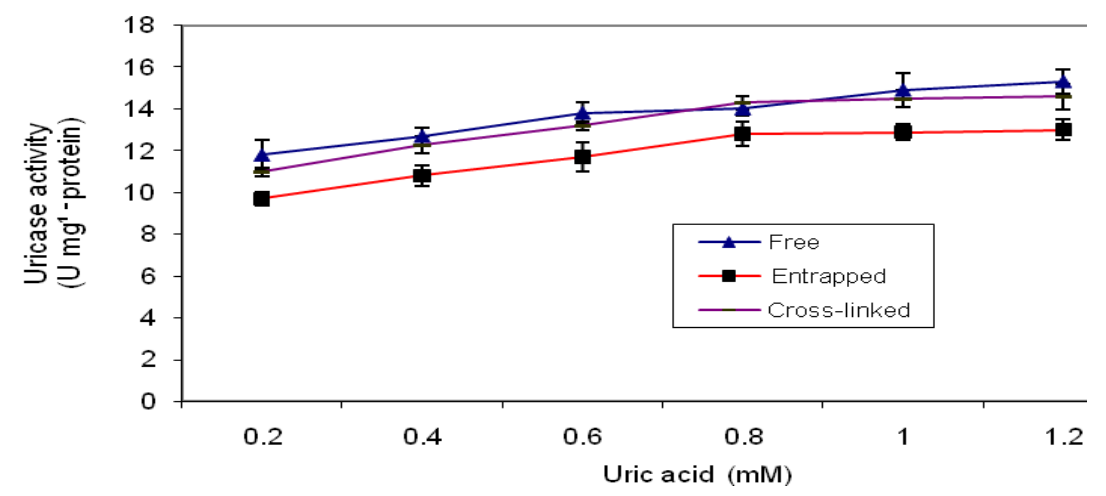

Fig.6 Lineweaver-Burk for Free, Entrapped and Cross-linked Uricase

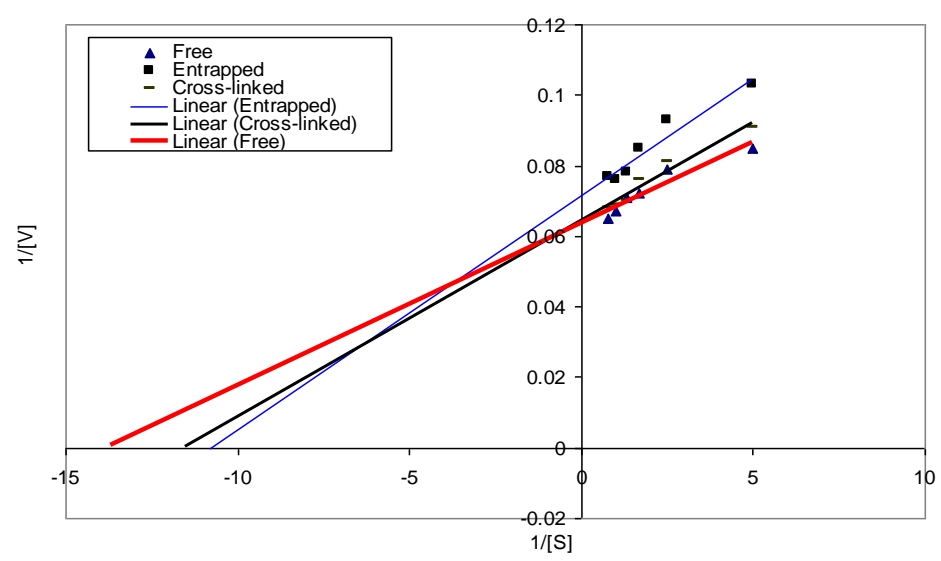

Fig.7 Effect of $\mathrm{pH}$ on the Activity of Free, Entrapped and Cross-linked uricase

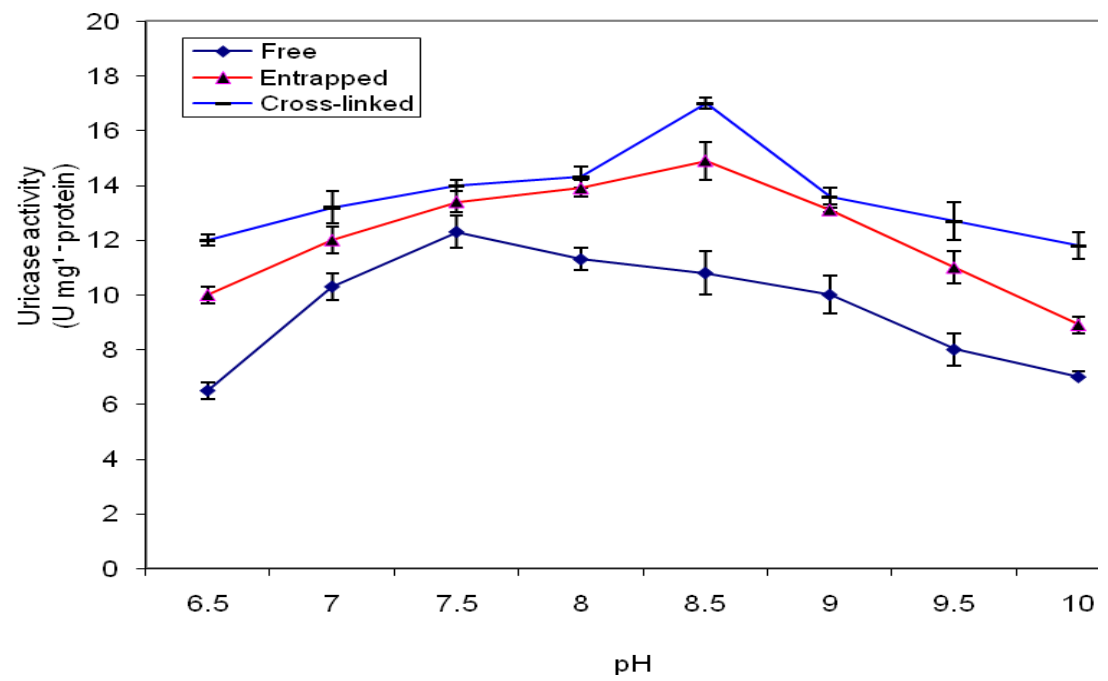


Fig.8 Effect of Temperature on Uricase Activity

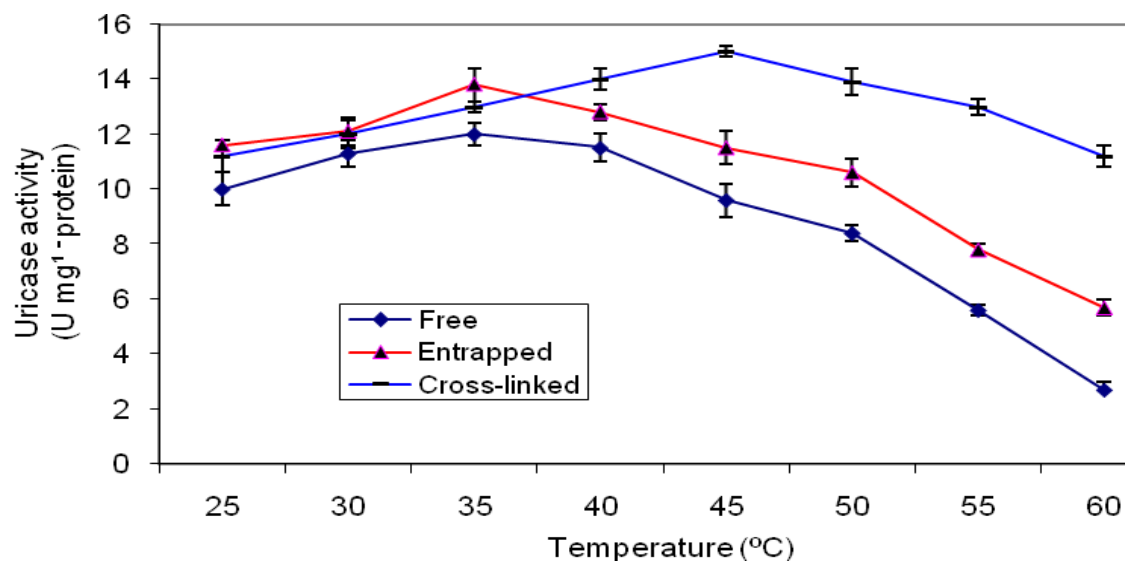

Fig.9 Reuse of Entrapped and Cross-linked Uricase

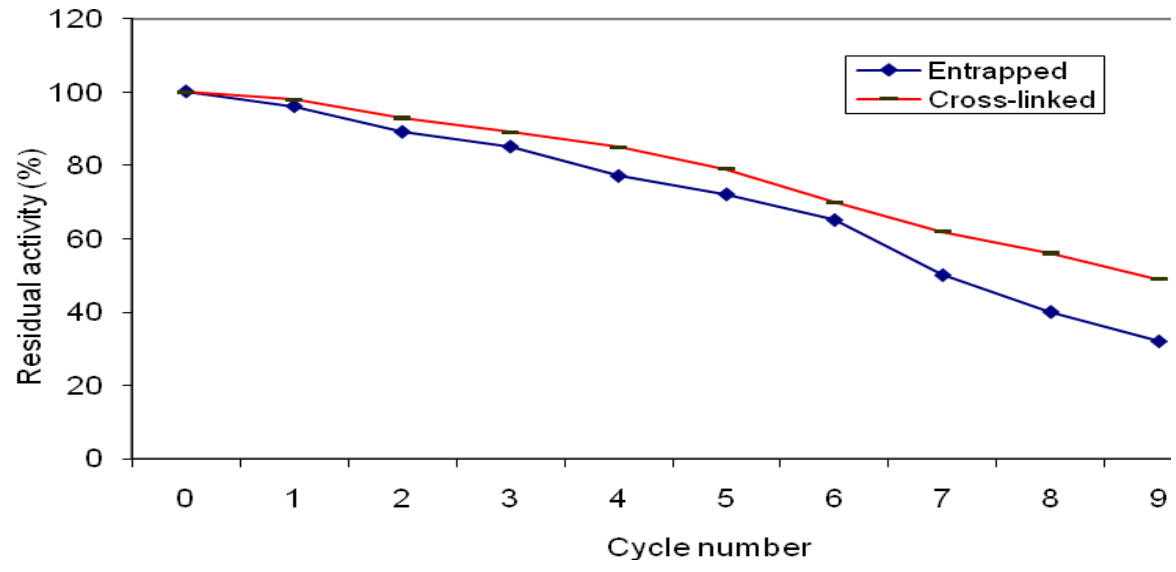

Fig.10 Effect of Pepsin on Uricase Activity.

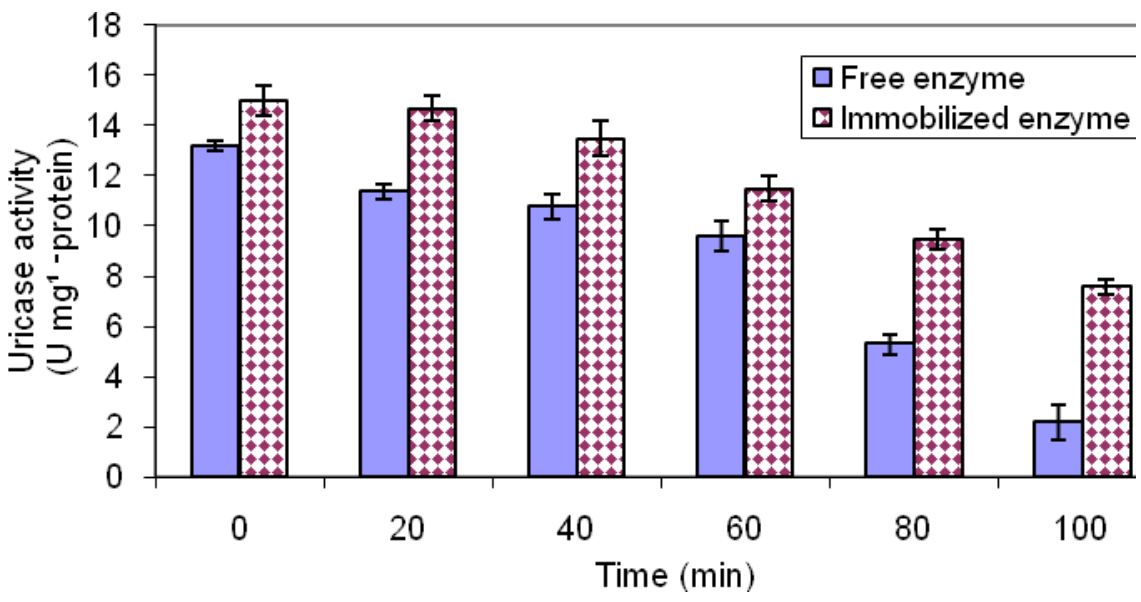


Fig.11 Effect of Trypsin on Uricase Activity

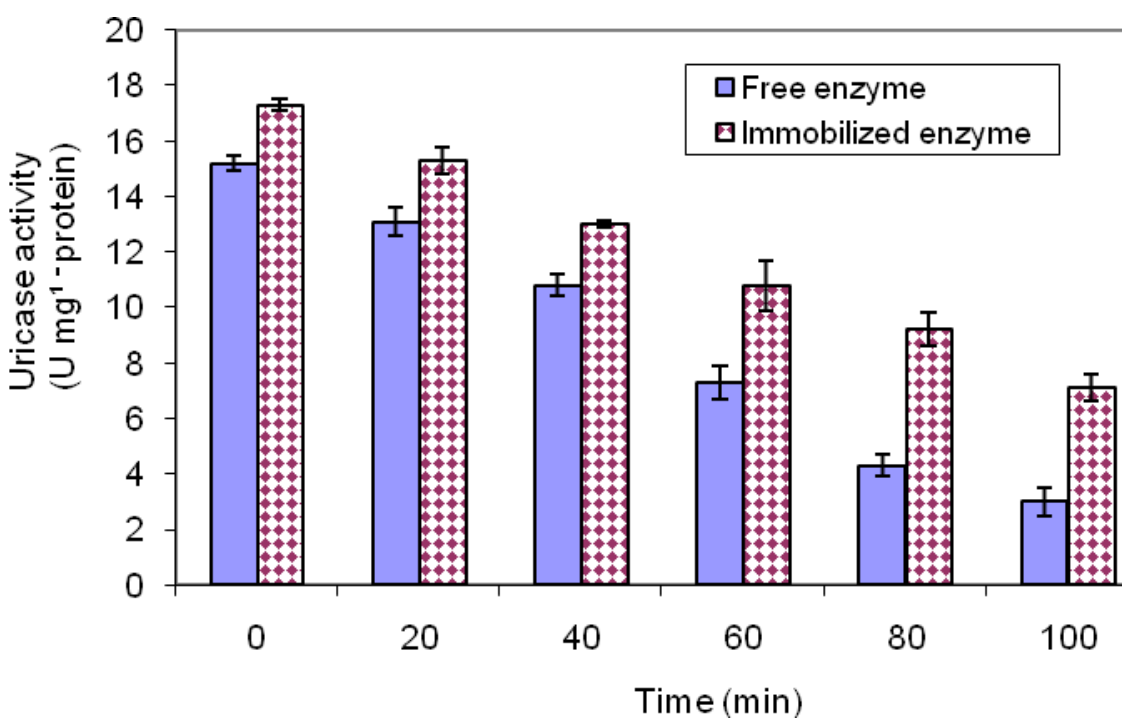

Fig.12 Desorptivity of Uricase by SDS

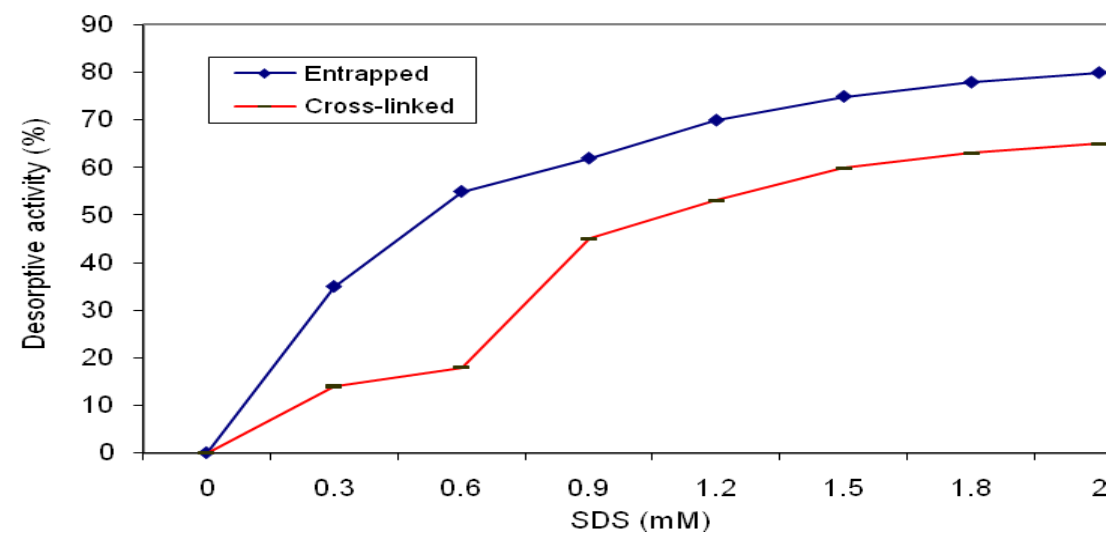

To investigate the possibility of reusing the immobilized enzyme by entrapment or cross-linking many times, the activity of the two forms of immobilized uricase was measured through successive ten cycles. The results in Fig. 9 indicate that uricase expressed appreciable activity throughout 9 cycles. The cross-linked uricase retained higher activity than entrapped enzyme throughout the ten cycles. The loss in activity upon reusing of immobilized preparation is a general observation. A lesser loss in activity in cross-linked enzyme preparation may be attributed to the cross- linking of enzyme molecules by glutaraldehyde. Significant loss in activity of immobilized xylanases has been reported by many workers. Alginate entrapped lipase was active after 10 cycles without any loss in activity (Bhushan et al., 2008).

The effect of proteolytic enzymes including pepsin (Fig.10) and trypsin (Fig. 11) on uricase activity was investigated at 200 units from each of the digestive enzymes. The results ross-linked urease was more resistant than the entrapment enzyme. 
The influence of sodium dodecylsulphate (SDS) on the desorptivity of the immobilized uricase either entrapped or cross-linked was carried out using various SDS concentrations. The results in Fig. 12 show that SDS was successful in desorption process of uricase than the entrapment or cross-linked. It was noticed that entrapped uricase was easier to be desorbed than the cross-linked enzyme throughout the various examined concentrations.

It is important to note that, after a number of reuse cycles, enzyme gets deactivated and it should be removed from the matrix. The studies performed on desorption were also meant to take into consideration the marginal amount of enzyme likely to be loosely entrapped.

It was found that SDS desorbed the enzyme from matrix even after cross-linking with glutaraldehyde. This might be due to the competition of anionic surfactant with enzyme surface bound to the matrix. Our results are in agreement with earlier reports which also provided similar suggestions (Ran et al., 2010). Researchers have always paid attention to strongly cross-link the enzyme molecules in the polymer network with the help of linkers, aggregators, carriers, and composite materials (Torabizadeh et al., 2014).

In conclusion, uricase expressed appreciable activity in leaves of Trigonella which is one of the important medical plants. Also, the enzyme was successfully immobilized by entrapment and cross-linking methods. In addition the immobilized enzyme was resistant to digestive enzymes including pepsin and trypsin. These characters provide the immobilized uricase an importance in medical application.

\section{References}

Abbas, A.A. 2016. Extraction, optimization of uricase From Aspergillus niger. Inter. J. Advan. Res., 4: 1865-1872.

Abdullah, S.K., Flayyih, M.T. 2015. Production, purification and characterization of uricase produced by Pseudomonas aeruginosa. Iraqi J. Sci., 56: 2253-2263.

Adamek, V., Kralova, B., Suchova, M., Valentova, O., Demnerova, K. 1989. Purification of microbial uricase. $J$. Chromatogr. B: Biomed. Sci. Applic., 497: 268-275.

Atalla, M.M., Farag, M.M., Eman, R.H., AbdEl-Lataif, M.S., Nehad E.A. 2009. Optimum conditions for uricase enzyme production by Gliomastixgueg. Malaysian J. Micr., 5: 45-50.

Atkins, C.A., Storer, P.J., Young, E.P. 1991. Translocation of nitrogen and expression of nodule-specific uricase (nodulin-35) in Robiniapseudoacacia. Physiol. Plant., 83: 483-491.

Bhosale, H., Shaheen, U., Kadam, T. 2016. Characterization of a hyperthermostablelkalinelipase from Bacillus sonorensis 4R. http://dx.doi.org/10.1155/2016/4170684

Bhushan, B., Pal, A., Kumar, S., Jain, V. 2015. Biochemical characterization and kinetic comparison of encapsulated haze removing acidophilic xylanase with partially purified free xylanase isolated fromAspergillus flavus MTCC 9390. J. Food Sci. Technol., 52: 191200.

Bhushan, B., Pal, A., Jain, V. 2015. Improved enzyme catalytic characteristics upon glutaraldehyde cross-linking of alginate entrapped xylanase isolated from Aspergillus flavus MTCC 9390. http://dx.doi.org/10.1155/2015/210784.

Bhushan, R., Parshad, G.N., Qazi, Gupta, V.K. 2008. Immobilization of lipase by 
entrapment in Ca-alginate beads. $J$. Bioac. Compat. Polym., 23: 552-562.

Bihzad, M.A., El-Shora, H.M. 1996. Phosphoenolpyruvate carboxylase from , a C 3-plant. J. Plant Physiol., 149: 669-676.

Bradford, M.M. 1976. Photometric methods for protein determination. Anal. Biochem., 72: 248-254.

Chang, M.Y., Juang, R.S. 2005. Activities, stabilities and reaction kinetics of three free and chitosan-clay composite immobilized enzymes. Enzyme Microb. Technol., 36: 75-82.

Christensen, T.M., Jochimsen, B.U. 1983. Enzymes of ureide synthesis in pea and soybean. Plant Physiol., 72: 56-9.

Cooney, D.G., Emerson, R. 1964. Thermophilic fungi: An account of their biology, activities, and classification. Free man W. H. Pub1. Co., San Fransisco. 188.

El-Shora, H.M. 2001. Properties and immobilization of urease from leaves of Chenopodium album (C3). Bot. Bull. Acad. Sin., 42: 251-258.

El-Shora, H.M., Abo-Kassem, E.M. 2001. Kinetic characterization of glutamate dehydrogenase of marrow cotyledons Aust. J. Plant Sci., 161: 1047-1053.

El-Shora, H.M., El-Naqeeb, L.A. 2014. Induction and biochemical characteristics of Cicer arietinumglutaminase. J. Environ. Sci., 43: 527537

El-Shora, H.M. 2002. Properties of phenylalanine ammonia-lyase from marrow cotyledons. 162: 1-7.

El-Shora, H.M., Aboukassem, E.A. 2001. Kinetic characterization of glutamate dehydrogenase of marrow cotyledons. Plant Sci., 161: 1047-1053.

El-Shora, H.M., Metwally, A.M. 2009. Effect of phytohormones and group selective reagents on acid phosphatase from Cladosporiumcladosporioides. Asian $J$. Biotechnol., 1: 1-11.

El-Shora, H.M., El-Huseeny, A.E., Ali, M.A. 2015. Characteristics of immobilized bacterial D-hydantoinase on alginate. Inter. J. Adv. Res., 3: 1948-1957.

Gekko, K., Timasheff, S.N. 1981. Mechanism of protein stabilization by glycerol: preferential hydration in glycerol-water mixtures. Biochem., 20: 4664-4676.

Graber, M., Combes, D. 1989. Effect of polyols on fungal alpha-amylase thermostability. Enzyme Microb. Technol., 11: 673-677.

Graber, M., Combes, D. 1989. Effect of polyols on fungal alpha-amylase thermostability. Enzyme Microbiol. Technol., 11: 673-677.

Hayat, S., Ahmed, A., Hussain, A., Mobin, M. 2001. Growth of wheat seedlings raised from the grains treated with 28 homobrassinolide. Acta Planta Physiol., 23: 27-30.

Huang, S.H., Wu, T.K. 2004. Modified colorimetric assay for uricase activity and a screen for mutant Bacillus subtilis uricase genes following StEP mutagenesis. Eur. J. Microbiol. Biotechnol., 271: 517-523.

Kai, L., Xiao, H.M., Xue, L.Z., Xiao, M.J., Xia, L., Guo, K.P. 2008. Purification and characterization of a thermostable uricase from Microbacterium sp strain ZZJ4-1. J. Microbiol. Biotechnol., 24: 401-406.

Kaur, S., Gupta, A.K., Kaur, N. 2000. Effect of GA3, kinetin and indole acetic acid on carbohydrate metabolism in chickpea seedlings germinating under water stress. Plant Growth Regul., 30: 61-70.

Klose, S., Stoltz, M., Munz, E., Portenhauser, R. 1978. Determination of uric acid on continuous-flow (AutoAnalyzer II and SMA) systems with a uricase/phenol/4aminophenazone color test. Clin. Chem., 24: 250-255.

Nancy, J.G., Susan, J.K., Edna, S., John, S.S., Michael, S. 2006. Control ofhyperuricemia in subjects with refractorygout, and induction of antibody againstpoly (ethylene glycol) (peg), in a phase I trial of subcutaneous 
pegylated urateoxidase. Arthritis Res. Ther., 8: 12.

Nanda, P., Babu, P.E., Fernandes, J., Hazarika, P., Dhabre, R.R. 2012. Studies on production, optimization and purification of uricase from Gliocladiumviride. Res. J. Biotechnol., 3: 35-46.

Nanda, P., JagadeeshBabu, P.E., Fernandes, J., Hazarika, P., Dhabre, R.R. 2012. Studies on production, optimization and purification of uricase from Gliocladiumviride. Res. Biotechnol., 3: 35-46.

Nirmal, N.P., Laxman, R.S. 2014. Enhanced thermostability of a fungal alkaline protease by different additives. Enzyme Research. http://dx.doi.org/10.1155/2014/109303.

Ohe, T., Watanabe, Y. 1981. Purification and properties of urate oxidasefrom Streptomycescyanogenus. J. Biochem., 89: 1769-1776.

Ran, S,. Jia, Y., Liu, W., Zhang, S., Wu, S., Pan, X. 2010. A facile method for improving the covalent crosslinking adsorption process of catalase immobilization, Biores. Technol., 101: 6285-6290.

Shah, H. 2011. Comparative effects of 4-ClIAA and kinetin on photosynthesis, nitrogen metabolism and yield of black cumin (Nigella sativa L.). Acta Bot. Croat., 70: 91-97.
Sola-Penna, M., Meyer-Fernandes, J.R. 1998. Stabilization against thermal inactivation promoted by sugars on enzyme structure and function: why is trehalose more effective than other sugars. Arch BiochemBiophys., 360: 410.

Theimer, R.R., Beevers, H. 1971. Uricase and allantoinase in glyoxysomes. Plant Physiol., 47: 246-51.

Torabizadeh, H., Tavakoli, M., Safari, M. 2014. Immobilization of thermostable $\alpha$-amylase from Bacillus licheniformis by cross-linked enzyme aggregates method using calcium and sodium ions as additives. J. Mol.Catal. B: Enzymatic, 108: 13-20.

Triantafyllou, A.Ö., Wehtje, E., Adlercreutz, P., Mattiasson, B. 1996. How do additives affect enzyme activity and stability in non-aqueous media. Biotechnol. Bioeng., 54: 67-76.

Triantafyllou, A., Wehtje, E., Adlercreutz, P., Mattiasson, B. 1997. How do additives affect enzyme activity and stability in nonaqueous media. Biotechnol.Bioengin., 54: 67-76.

Yildiz, H. 2005. Immobilization of glucose oxidase in conducting graft copolymers and determination of glucose amount in orange juices with enzyme electrodes. Int. J. Boil. Macromol., 37: 174-178.

\section{How to cite this article:}

Hamed M. El-Shora, AbdelAziz F. AbdelAziz and Hoda M. Kondi. 2016. Response of Free and Immobilized Uricase from Fenugreek Leaves to Various Treatments and Digestive Enzymes. Int.J.Curr.Microbiol.App.Sci.5(4): 1050-1061. doi: http://dx.doi.org/10.20546/ijcmas.2016.504.120 